\title{
Moving the Shh Source over Time: What Impact on Neural Cell Diversification in the Developing Spinal Cord?
}

\author{
Cathy Danesin * and Cathy Soula * \\ Centre de Biologie du Développement (CBD) CNRS/UPS, Centre de Biologie Intégrative (CBI), \\ Université de Toulouse, 31520 Toulouse, France \\ * Correspondence: cathy.danesin@univ-tlse3.fr (C.D.); catherine.soula@univ-tlse3.fr (C.S.); \\ Tel.: +33-5-61-55-64-23 (C.D. \& C.S.)
}

Academic Editors: Henk Roelink and Simon J. Conway

Received: 28 February 2017; Accepted: 6 April 2017; Published: 12 April 2017

\begin{abstract}
A substantial amount of data has highlighted the crucial influence of Shh signalling on the generation of diverse classes of neurons and glial cells throughout the developing central nervous system. A critical step leading to this diversity is the establishment of distinct neural progenitor cell domains during the process of pattern formation. The forming spinal cord, in particular, has served as an excellent model to unravel how progenitor cells respond to Shh to produce the appropriate pattern. In recent years, considerable advances have been made in our understanding of important parameters that control the temporal and spatial interpretation of the morphogen signal at the level of Shh-receiving progenitor cells. Although less studied, the identity and position of Shh source cells also undergo significant changes over time, raising the question of how moving the Shh source contributes to cell diversification in response to the morphogen. Here, we focus on the dynamics of Shh-producing cells and discuss specific roles for these time-variant Shh sources with regard to the temporal events occurring in the receiving field.
\end{abstract}

Keywords: Sonic Hedgehog; neural tube patterning; notochord; medial floor plate; lateral floor plate; neurons; glial cells; amniotes; zebrafish

\section{Introduction}

The functional complexity of the vertebrate central nervous system is reflected by the large variety of neurons that form complex processing networks but also by the diversity of their indispensable glial cell partners, mainly composed of astrocytes and oligodendrocytes. Generation of this large array of distinct neural cell types is initiated at early stages of embryonic development and depends on the influence of a limited number of signalling cues. Among them, the morphogen factor Sonic Hedgehog (Shh) appears central in governing the specification of a variety of neuronal and glial cell lineages. When and how Shh controls the identity and pattern of neural cell types is best understood in the ventral region of the forming spinal cord. In this tissue, Shh acts as a long-range morphogen to direct the pattern of neurogenesis by conferring positional information to neural progenitor cells. During the transformation of the neural plate into the neural tube, Shh triggers the elaboration of five discrete domains of progenitor cells, named p3, pMN, p2, p1, and p0, arrayed along the dorso-ventral axis [1,2]. Identities of progenitor domains are based on the combinatorial expression of a set of transcription factors and these specific combinatorial codes are necessary and sufficient to specify the neuronal subtypes that each domain generates [3,4]. The pMN progenitor domain gives rise to motor neurons (MNs), while the p3, p2, p1, and p0 progenitor cells generate V3, V2, V1, and V0 interneurons, respectively (Figure 1). After completion of neuronal production, a neuronal to glial 
switch operates in the ventral spinal cord and a similar principle of progenitor domain organization regulates the generation of distinct glial cell sub-types [5] (Figure 1). Distinct populations of astrocytes originate from the $\mathrm{p} 3, \mathrm{p} 2, \mathrm{p} 1$ and $\mathrm{p} 0$ domains [6-8] while progenitor cells of the $\mathrm{pMN}$ domain generate oligodendrocytes [9-12].

(a)

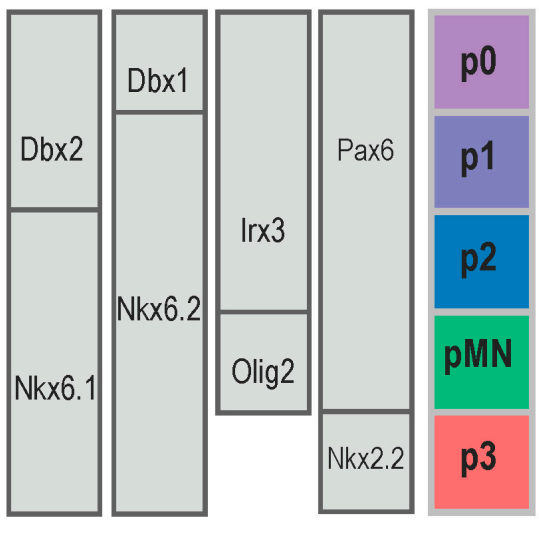

(b)

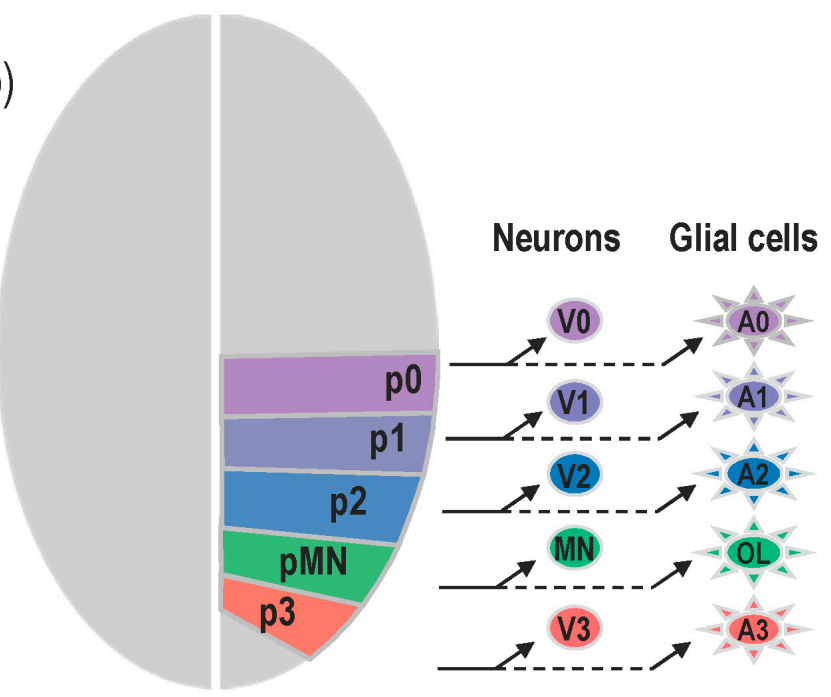

Figure 1. Domain organisation of ventral neural progenitor cells controls generation of distinct neuronal and glial cell subtypes. (a) Five progenitor domains, p3, pMN, p2, p1 and p0, are established in response to Shh along the ventral to dorsal axis. Progenitor cells in each domain are characterised by the combinatorial expression of transcription factors indicated on the left. (b) Each progenitor pool sequentially generates a specific sub-type of neurons and glial cells. Progenitor cells of the p0, p2 and p3 domains first produce three distinct types of ventral interneurons (V0-V3) and, later on, change their fate to generate ventral astrocytes (A0-A3). Progenitor cells of the pMN domain characterised by Olig2 expression first generate motor neurons $(\mathrm{MN})$ and switches to production of oligodendroglial cells (OL).

Many studies have been conducted to elucidate the complex process of patterning establishment in response to Shh and, although still incomplete, significant progress was made in understanding the fundamental basis of this process. In the presumptive spinal cord region, Shh is initially secreted from the notochord, a population of mesodermal cells, acting as an organizing centre for the overlying neural tissue $[13,14]$. In amniotes, Shh provided by the notochord induces the formation of a second centre of Shh production at the midline of the neural tube, named the floor plate [15-17]. Shh provided by these ventral axial structures spreads through the ventral neural tube and establishes a gradient of activity necessary for pattern formation [18-20]. This graded information is sensed by ventral progenitor cells that express Patched (Ptch1), the Shh receptor, and is transduced into the receiving cells by the transmembrane protein Smoothened (Smo), which in turn controls the downstream activation of Gli transcriptional effectors [2,21]. Progenitor cells then respond to the graded Shh signalling by regulating the expression of homeodomain and basic helix-loop-helix transcription factors that have been subdivided into two groups, termed class I and II proteins, on the basis of their mode of regulation by Shh signalling [22]. Class I genes, such as Irx3, and Pax6 are repressed by distinct thresholds of Shh activity, while class II genes, including Nkx6.1, Nkx2.2 and Olig2, are activated by graded Shh signalling (Figure 1). The combinatorial expression of class I and II proteins together with cross-repressive interactions between them contribute to establish boundaries of gene expression that divide the ventral neural tube into the five above-mentioned progenitor domains [2]. As an example,

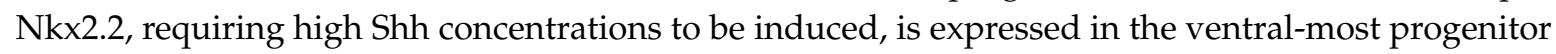
cells of the p3 domain, whereas Olig2, induced by lower Shh concentrations, is expressed more dorsally, 
in the pMN domain [23]. However, Shh concentration is not the only level of regulation as duration of exposure to Shh also influences the response to the morphogen, with ventral identities requiring longer time of Shh exposure to be established $[24,25]$. Therefore, progenitor domains form sequentially and the ventral-most $\mathrm{p} 3$ domain emerges later than the dorsally located pMN domain [24-29]. Expression of Olig2 in the ventral neural tube is indeed initiated before that of Nkx2.2. The ventral-most cells further activate the high threshold Shh responsive gene Nkx2.2 [28,30,31] which is in turn responsible for the downregulation of Olig2 and, thereby, for the formation of the two non-overlapping domains. Accordingly, progressive formation of ventral progenitor domains is accompanied by a temporal increase in the amplitude of the Shh gradient $[19,20]$. However, the levels of Shh signalling in progenitor cells are also dynamic and do not strictly correlate Shh protein distribution $[20,27,32]$. This adaptive response, referred to as temporal adaptation, is known to rely on dynamics of downstream Gli activity as well as regulation of co-receptors or inhibitors of Shh signalling [20,26,27,32,33]. Feedback activities exerted by homeodomain proteins also modulate the strength of Shh signalling in the ventral-most progenitor cells [28]. Thus, production of the appropriate pattern results from a complex interplay between the threshold of the Shh signal and the temporal adaptive response of receiving cells that actively collaborate to interpret and refine the morphogen gradient.

After that time, and only once neurons have been generated, progenitor cells of the ventral spinal cord change their fate and start generating glial cells in a process called the neuroglial switch. This process has been particularly well studied for the oligodendrocyte lineage. Most oligodendrocytes of the spinal cord are known to originate from Olig2-expressing progenitor cells $[34,35]$. Therefore, in the ventral spinal cord, newly specified oligodendrocyte precursor cells are positioned in the pMN domain, which, just before the initiation of gliogenesis, generates MNs. Although originating from the same progenitor domain, MNs and oligodendroglial cells have been shown to arise from distinct progenitor cells in the zebrafish embryo [36]. In amniotes, whether MNs and oligodendrocytes originate from common or separate lineages in vivo remains to be established [5]. Strikingly, the decision to produce oligodendroglial cells, long after patterning establishment, still depends on Shh signalling activity [37-40]. A set of studies reported that this cell fate change relies on a temporal rise of Shh signalling activity that occurs immediately prior to the MN to oligodendroglial cell fate switch [38,41-43]. Accordingly, this late activation of Shh signalling results in a reorganization of the ventral progenitor domains. Expression of Nkx2.2 extends dorsally and starts overlapping with the pMN domain precisely where MN production stops in the ventral spinal cord [39,42-46]. This leads to the formation of a new domain, named the $\mathrm{p}^{*}$ domain, populated by progenitor cells that co-express Olig2 and Nkx2.2. Strikingly, at that time, Nkx2.2 no longer represses Olig2 and co-expression of the two transcription factors is critical to drive $\mathrm{p}^{*}$ progenitor cells towards the oligodendroglial fate [44]. Thus, the Shh signal must not only be provided until late developmental stages but also strengthened to allow full accomplishment of the neural differentiation repertoire in the ventral spinal cord.

Parallel to these events, important temporal changes in the identity and position of cells that provide the Shh signal are also known to occur both in amniotes and zebrafish, highlighting the dynamic nature of Shh source cells over time (Figure 2). The notochord is the first localised source of Shh that comes in contact with the ventral caudal neural tube as it closes. The ventral medial cells of the neural tube, commonly known as floor plate (FP) cells, have long been recognised to also express Shh. In the past years, the mechanisms that control the development of the FP have received much attention and led to the proposal of a model in which Shh, secreted from the notochord, induces FP formation in the overlying neural tube $[47,48]$. This model came from experiments performed in amniotes, showing that notochord-derived signals can induce FP differentiation both in vitro and in vivo [49-53]. Conversely, absence of the notochord, resulting from notochord ablation or mutations that disrupt its formation, is accompanied by failure in FP induction [49,51,52,54-56]. Further studies rapidly recognised Shh to be the main notochord-provided signal responsible for triggering FP induction $[15,16,29,57]$. However, whether the notochord-provided Shh is truly responsible for FP cell induction has been a matter of controversy. Specification of FP cells in chicken and zebrafish has been 
proposed to occur earlier, within the node, independently of the inductive activity of the notochord (for review, see $[17,58]$ ). Later in development, a third source of Shh was recognised to form in the ventral-most neural progenitor cells $[40,43,59]$. These cells, because they differentiate on either side of the floor plate, were named the lateral floor plate (LFP) cells. To avoid confusion of terms, medial cells of the neural tube that are the first to activate Shh will be named the medial floor plate (MFP) instead of FP cells in the following sections. Here, and in an attempt to pave the way for the specific roles for these time-variant Shh sources, we review the temporal dynamics of Shh-source cells and relate these sequential changes to the control of developmental transitions over spinal cord development.

(a)

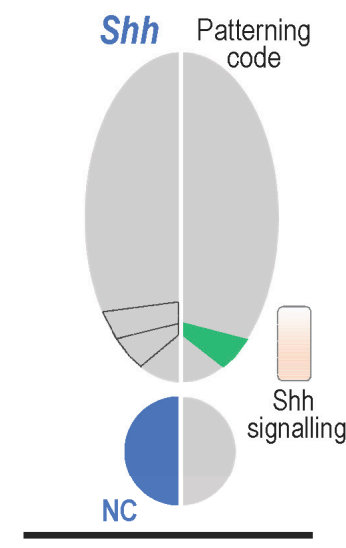

t1

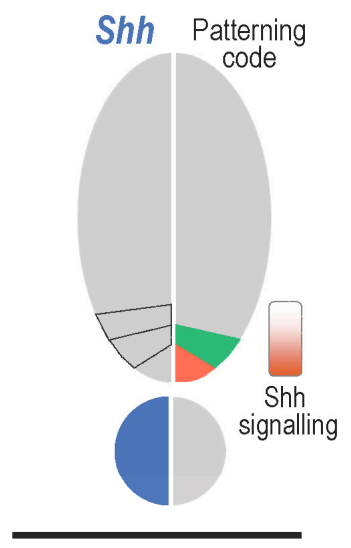

t2

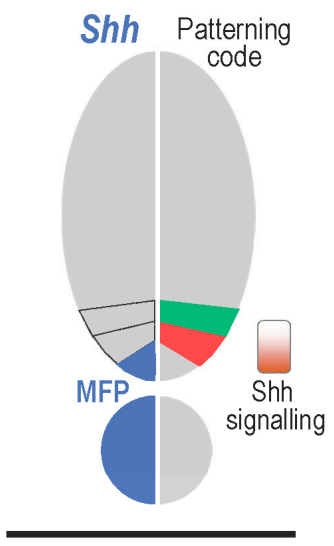

t3

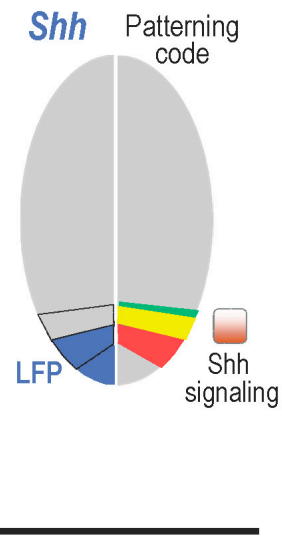

t4

(b)

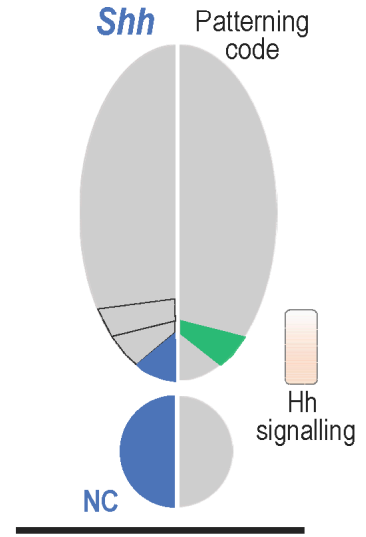

t1

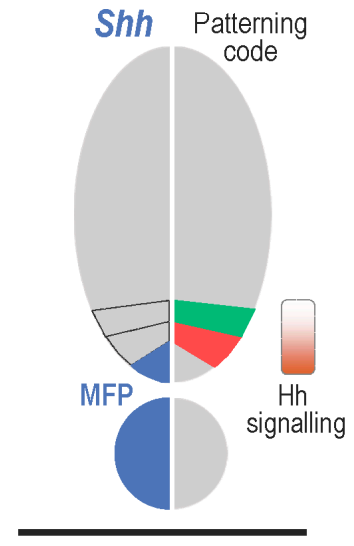

t2

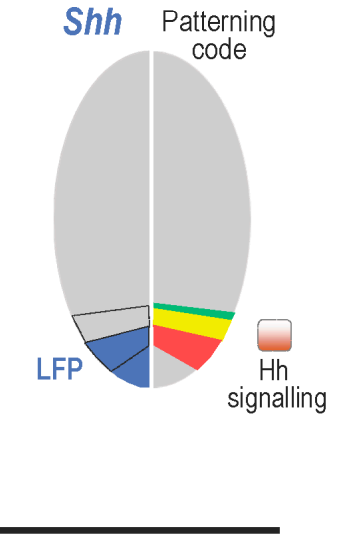

t3

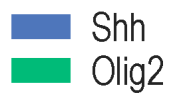

Nkx2.2/Foxa2

Nkx2.2/Olig2

Figure 2. Dynamics of Shh source cells along with neural patterning progression in amniotes (a) and zebrafish (b). (a) Shh, first provided by the notochord (t1), induces a low-dose response program in the neural tube revealed by Olig2 expression in ventral progenitor cells. Formation of this pre-pattern is observed over eight days of development (E8) in the mouse embryo [19,26,29]. As development proceeds 
(t1-t3), increasing doses of Shh are progressively provided by the notochord. In response to the resulting activation of Shh signalling in the receiving field, ventral progenitor cells upregulate Nkx2.2 and Foxa2 (t2). Expression of these high threshold Shh responsive genes progressively extends dorsally (t3) and Olig2 is downregulated in the ventral-most progenitor cells due to the repressive activity of $\mathrm{Nkx2.2}$. In parallel, Shh expression is activated in ventral midline cells ( $\mathbf{t} 3$ ), thus completing MFP cell differentiation. In these cells, Shh signalling is downregulated and Nkx2.2 expression is turned off. At that time, patterning of neuron-producing domains is achieved. The $\mathbf{t} \mathbf{2}-\mathbf{t} \mathbf{3}$ period of development corresponds roughly to the period between the ages of E1.5-E2 and E8.5-E9.5 in chicks and mice, respectively $[19,26,28,29,60]$. From that time, MFP becomes the main provider of Shh required to maintain progenitor domains. This is paralleled by a general decrease of Shh signalling activity in ventral progenitor cells while they start generating neurons $[20,27]$. After a period of several days (t4), ventral progenitor cells co-expressing Nkx2.2 and Foxa2 activate Shh expression to form the LFP. This is associated with a decay of Shh signalling in these cells. At that time, Shh signalling is activated in dorsal adjacent progenitor cells that subsequently upregulate Nkx2.2. This change in pattern organization leads to formation of a novel progenitor domain populated by Olig2/Nkx2.2-coexpressing cells that change their fate to generate glial cells. $\mathbf{t} 4$ corresponds to E5.5 in chicks and E11.5 in mice [42,43]. (b) At initiation of neural tube patterning in zebrafish (t1), Hedgehog ligands are provided by the notochord but also by MFP cells. The time course of Olig2 and Nkx2.2 expression in ventral progenitor cells is conserved. Pattern formation of ventral progenitor domains (t1-t2) takes place over a short period of time, from 14 to 16 hours post-fertilization (hpf) [43,61,62]. After a period of approximately one day (t3), Shh expression expands laterally into the Nkx2.2-expressing domain to form the LFP and the subsequent reorganization of the ventral patterning that is in place from $36 \mathrm{hpf}$ in zebrafish $[40,43]$.

\section{Specific Functions of the Notochord-Derived Shh}

\subsection{Shh Provided by the Notochord Triggers MFP Differentiation}

Although some controversies have arisen concerning the requirement of the notochord-provided Shh for MFP cell induction, recent data confirm its role in controlling MFP differentiation in amniotes. In mouse embryos lacking functional Shh, while initial development of the notochord proceeds properly, MFP cells fail to differentiate $[63,64]$. The prospective MFP cells are also known to be the direct target of the notochord-derived Shh in mice [65]. For triggering MFP cell differentiation, notochord cells must provide high levels of Shh signalling. This was first recognised from in vitro experiments showing that treatment of neural plate explants with high concentrations of Shh is necessary to trigger the expression of MFP genes [16]. In agreement with these experimental observations, at the time of MFP cell differentiation in vivo, most of the secreted Shh is retained at the surface of notochord cells while these cells are in direct contact with the basal surface of the neural tube $[16,18,19,26,29]$. Identification of the temporal sequence of genes regulated by Shh in the prospective MFP cells further reinforced this assumption. The earliest reported event occurring in response to the notochord-provided Shh in prospective MFP cells is the concomitant activation of Nkx6.1 and downregulation of Pax6, two transcription factors activated and repressed by high levels of Shh signalling, respectively $[4,19,26,66]$. Shortly afterwards, Nkx2.2 and Foxa2 (also known as HNF3 $\beta$ ), both being direct targets of Shh signalling and also known to respond to high doses of the morphogen, are upregulated in these cells [19,26,28-32,67-71]. This dynamic transcriptional program in prospective MFP cells was supposed to reflect increasing levels of Shh signalling over time, as suggested by in vitro assays showing that elaboration of this transcriptional program indeed depends on increasing Shh concentration thresholds $[4,29,66]$. Accordingly, in an elegant study based on the direct visualization a GFP tagged version of Shh, Chamberlain and collaborators (2008) were able to show that the level of Shh provided by the notochord increases progressively as ventral medial cells go from expressing $\mathrm{Nkx6.1} \mathrm{to} \mathrm{upregulating} \mathrm{Nkx2.2.} \mathrm{At} \mathrm{the} \mathrm{same} \mathrm{time,} \mathrm{prospective} \mathrm{MFP} \mathrm{cells} \mathrm{themselves}$ contribute to their sensitization to the Shh signal by expressing the Shh signal enhancers Cdo and Gas1, both required for MFP formation [72-74]. Another essential parameter in the control of MFP 
development is the competence of neural cells to respond to Shh. Grafts of notochord explants initially highlighted that there is only a narrow time window when full differentiation of MFP cells can take place $[29,49,59]$. Another signal, FGF, was further shown to provide this competence by maintaining transient expression of the transcription factor $\mathrm{Nkx2.1}$ in ventral medial cells of the neural tube [75]. The intersection of FGF signal emanating from the caudal part of the embryo and high threshold Shh signals secreted by the notochord is therefore recognised to provide a spatial and developmental time window that determines generation of MFP cells from ventral medial cells of the neural tube.

At a certain time point, while still in contact with the notochord, prospective MFP cells become refractory to the Shh signalling, a key step in maintaining their identity. If Shh signalling is artificially forced for a long period of time, the prospective MFP cells do not differentiate properly and instead convert their identity to ventral neural progenitors [29,32]. Downregulation of Gas1, an enhancer of the Shh signalling whose expression is negatively regulated by Shh, has been proposed to contribute to the attenuation of Shh signalling in MFP cells [72-74]. This attenuation is likely to also rely on the repression of Gli2, the predominant actor in relaying the Shh signal in MFP cells, resulting from Foxa2 expression in these cells [29,76-78]. From this time on, the final steps of MFP differentiation are mainly coordinated by Foxa2 that orchestrates induction of the MFP genes Arx and Nato3 and, indirectly, downregulation of Nkx2.2, a cellular context required for activation of Shh expression in MFP cells $[29,60,79,80]$. Therefore, Foxa2 itself activated by the notochord-provided Shh, is the key factor that relays Shh signalling for full differentiation of MFP cells.

Thus, proper differentiation of the MFP relies on a transient burst of Shh signalling provided by the notochord. After that, Shh continues to be expressed by MFP cells independently of Shh signalling, in agreement with the physical separation of the notochord and MFP cells that occurs at later developmental stages.

\subsection{Shh Provided by the Notochord Induces Neural Tube Patterning in Amniotes}

The role of Shh emanating from the notochord is not limited to formation of the MFP. Notochord-provided Shh is also recognised to play a key role in the elaboration of the p3, pMN and p2 ventral domains $[19,25,26,76,81]$. In chicks and mice, patterning of the ventral neural tube is initiated even before Shh is expressed in prospective MFP cells [19,25,26,76,81]. In Gli2 mutant mouse embryos lacking MFP cells, production of Shh from the notochord is sufficient to pattern the ventral neural tube, although neural progenitor cells appear to be reduced in number in some domains [76,82]. Likewise, and again despite reduced domain sizes, the neural tube patterning arises in mice, where Shh removal is genetically driven in medial neural cells [25,81]. Importantly, Shh emanating from the notochord is recognised to reach the neural target field by traveling through ventral medial cells as the patterning process is under way [19].

\subsection{Shh Provided by the Notochord Favours Progenitor Cell Proliferation in Amniotes}

Establishment of the neural tube patterning occurs at the same time as the tissue grows [83], a process also regulated by notochord-derived Shh. Notochord removal has long been known to reduce the size of the neural tube $[84,85]$, while implantation of a notochord fragment lateral to the neural tube enhances proliferation of progenitor cells $[53,86]$. Shh was further recognised to be the notochord signal responsible for causing over-proliferation of neural progenitor cells [87-89]. In support of this, mouse embryos depleted for the two endogenous inhibitors of the pathway, Ptc1 and Hip1, exhibit a noticeably enlarged neural tube; this is observed before Shh expression in MFP cells [26].

\subsection{Role of the Notochord-Provided Shh in Zebrafish}

Although one of the first studies involving the notochord-derived Shh in the control of neural cell identity was performed in the zebrafish embryo [61], further analyses revealed an alternative model for MFP cell induction. Notably, MFP develops properly in zebrafish embryos, carrying a mutation in no tail-a (a Brachyury ortholog) and in which notochord cells are absent, thus questioning 
the involvement of Shh signalling in zebrafish MFP cell induction [90,91]. MFP cells were further shown to form normally in zebrafish embryos homozygous for a deletion of sonic you, the zebrafish Shh gene [92-94]. However, in contrast to mice and chicks, in which Shh is the only Hedgehog gene expressed by the notochord, in zebrafish, midline mesodermal cells also express echidna hedgehog, an Indian hedgehog homologue $[95,96]$. The third Hedgehog zebrafish gene, tiggywinkle hedgehog (twhh), is not expressed in the notochord but is activated together with Shh in MFP cells [97,98]. Yet, proper induction of MFP cells in Shh mutant embryos does not appear to reflect cooperation with the other members of the Hedgehog family since MFP cells differentiate in Shh mutants injected with morpholinos used to knock down twhh [98] or twhh plus ehh [99]. Similarly, mutations in the zebrafish smoothened (Smo) or you-too (Gli2) genes or treatment with cyclopamine, a Smoothened inhibitor, only partially affect MFP differentiation [62,100-102]. Rather, MFP formation is altered in cyclops and one-eyed pinhead mutants that lack the Nodal-related-2 protein and its receptor, respectively [103-108]. Therefore, instead of Shh, the TGF $\beta$ signalling factor Nodal has been proposed to be the primary signal responsible for MFP cell specification in zebrafish. Accordingly, expression of Foxa2 (also known as Axial in zebrafish), also required for MFP differentiation in zebrafish, has been proposed to depend on Nodal, instead of Shh [109]. In support of the view that the Hedgehog signalling plays a less prominent role in zebrafish than in amniotes, the two Nkx2.2 paralogs, Nkx2.2a and $\mathrm{Nkx2.2b}$, are never activated in the zebrafish MFP cells $[43,62,110]$. However, a more recent study showing that Hedgehog signalling, together with Nodal, contributes to induce MFP cells within a short time window spanning from gastrulation to early somitogenesis, challenged the model of Hedgehog-independent induction of MFP cells in zebrafish [29]. Although still discussed for its function in MFP induction, Hedgehog signalling is nevertheless recognised to be required for the maintenance of MFP cell identity in zebrafish. Although zebrafish embryos can form MFP cells in the absence of Hedgehog signalling activity, they indeed prematurely lose expression of MFP markers as development proceeds [100]. Moreover, in cyclops and one-eyed pinhead mutant embryos, MFP cells finally form in a Shh-dependent manner $[107,111]$. Thus, both Hedgehog and Nodal contribute to MFP formation in zebrafish. Based on some evidence that Nodal also plays a role in MFP formation in amniotes, the apparent differences in MFP formation between zebrafish and amniotes likely reflect varying contributions of Hedgehog and Nodal signalling to MFP induction and maintenance (for review, see [17] ). Another noticeable aspect of zebrafish MFP formation is that differentiation of these cells and initiation of neural tube patterning do not follow the same temporal sequence as in amniotes. In zebrafish, MFP cell identity, i.e., expression of Shh and Twhh in these cells, is set up prior to establishment of neural tube patterning $[12,43,61,62,98,110]$. Therefore, in zebrafish, as discussed below, the MFP instead of the notochord is likely the main source of Hedgehog signalling required for formation of ventral neural progenitor domains.

\section{What Is the Relevance of Forming the MFP as a Secondary Signalling Centre?}

\subsection{Shh Provided by MFP Cells Is Required to Maintain Progenitor Domains in Amniotes}

In amniotes, after the establishment of the neural tube patterning, the notochord loses its contact with the neural tube and regresses away from the developing spinal cord as it becomes surrounded by sclerotomal cells. This regression process takes place as neuronal production in the ventral spinal cord is on the way [81]. Therefore, during neurogenesis, the source of Shh is mostly the MFP $[19,81]$. As mentioned above, Gli2 mutant mouse embryos that fail to develop a MFP are still capable of specifying all primary Shh-dependent ventral neural progenitor populations $[76,82]$. In these embryos, MNs, while occupying a more ventral position, still differentiate. At first glance, this might reflect that Shh from MFP cells is dispensable for MN differentiation. However, in Gli2 mutant mouse embryos, the notochord does not regress but remains in close contact with the developing spinal cord while it continues to express Shh. Therefore, due to the persistent proximity of the notochord to the ventral spinal cord, it is conceivable that Shh emanating from this tissue might be sufficient to 
compensate for the loss of MFP cells, precluding any conclusion on the requirement of MFP-derived Shh for induction of neuronal differentiation. A set of more recent studies, however, supports an essential role of the MFP-provided Shh for maintenance of the ventral patterning. Cyclopamine treatment, used in chicken to interrupt Shh at different time windows after establishment of the neural tube patterning, indicated that continued Shh signalling is required to maintain the identities of ventral progenitor cells $[25,33,39]$. Notably, Olig2 expression is more severely affected than that of Nkx2.2, indicating differential requirement of MFP-provided Shh to maintain the pMN and p3 domains $[25,33,39]$. Furthermore, mice containing conditional null alleles for Shh were used to test whether an extended period of Shh signalling is also necessary for maintaining the progenitor domains in the mouse neural tube. Deletion of Shh from MFP cells was performed using mice containing a conditional null allele for Shh and transgenes that activate Cre expression in ventral cells only after patterning establishment [25]. In these double transgenic embryos, expression of Shh by the notochord, as well as initial formation of the progenitor domains, are unaffected and, in contrast to what has been observed in embryos lacking Gli2, the notochord separates normally from the neural tube. Similarly to what was observed in chicken, a marked decrease in the number of cells expressing Olig2 and,

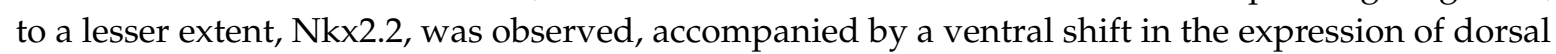
markers. Similar observations were more recently reported using a distinct transgenic Cre line that induces genetic deletion of Shh specifically in the MFP, using an MFP-Foxa2-pecific driver [81]. Finally, a reduced number of Olig2-expressing cells was also found in mouse embryos depleted for the MFP transcription factor Arx, in which the levels of Shh expression are left intact in the notochord but markedly reduced in MFP cells [60]. It is therefore assumed that the MFP-derived Shh plays a key role in maintaining the identity of neural progenitor cells after it has been assigned and subsequently the production of the complete set of neurons in the ventral spinal cord. In the chick neural tube, a direct influence of Shh on the control of neural progenitor cell cycle progression and survival has also been evidenced to occur until late stages of development [112]. Therefore, MFP-derived Shh is also likely required to maintain progenitor cell proliferation and prevent cell death over spinal cord development.

\subsection{MFP-Provided Shh Is Required to Achieve the Neural Tube Patterning in Zebrafish}

Spatial patterning of the neural tube is known to be conserved in zebrafish [113] and to also depend on Hedgehog signalling for its establishment [12,40,62,113-116]. However, the temporality of ventral progenitor domain formation relative to the expression of Hedgehog proteins in the notochord and MFP cells differs compared to amniotes. As mentioned above, zebrafish MFP cells become a source of Hedgehog proteins at earlier stages compared to amniotes, i.e., from mid-gastrula stages [61,98]. At the same time, some patterning genes, including Olig2, Nkx6.1 and Nkx6.2, are already expressed in medial cells of the neural plate $[12,62,114]$. This therefore opens up the possibility that expression of these genes might be activated by Hedgehog proteins provided by MFP cells, together with or in place of notochord cells. It is worth noting that preventing Hedgehog signalling at early somitogenesis stages, although reducing the levels of Olig2 and Nkx6.1/2 expression, does not totally abolish their expression $[12,62,114]$. Therefore, in zebrafish, additional signals together with Hedgehog proteins might contribute to initiate patterning of the ventral neural tube. In contrast, elaboration of the p3 and pMN domains requires Hedgehog signalling activity [43,62]. Formation of these two domains is achieved during the segmentation period, by the activation of Nkx2.2a, the Nkx2.2 orthologue, together with downregulation of Olig2 in $\mathrm{p} 3$ progenitor cells [43]. The prominent role of the MFP-provided Hedgehog proteins in patterning the $\mathrm{p} 3$ and $\mathrm{pMN}$ domains in zebrafish was further highlighted by the identification of a novel modulator of Hedgehog signalling activity, named Sulf1 [41-43]. Sulf1 is an extracellular sulfatase known to regulate signalling pathway activities by modulating the interaction of ligands with heparan sulphate proteoglycans (HSPGs) at the cell surface [117]. In Drosophila, Sulf1 has opposing functions, enhancing Hedgehog release from its source and reducing Hedgehog signalling activity in the responding cells [118]. In the vertebrate spinal cord, Sulf1 only behaves as a positive modulator of Shh signalling [41-43]. The enzyme is known to enhance Shh signalling activity in a 
cell-autonomous manner by stimulating production of active forms of Shh from its source cells [43]. In zebrafish, at the time of patterning establishment, Sulf1 is expressed in MFP cells but not in notochord cells $[43,119]$. Strikingly, Sulf1 expression in MFP cells follows Hedgehog protein expression but shortly precedes activation of Nkx2.2a in progenitor cells of the p3 domain [43]. Depletion of Sulf1, while not affecting the timing of Olig2 activation, is, however, sufficient to prevent establishment of the p3 domain, a patterning defect accompanied by defective generation of $\mathrm{V} 3$ interneurons but normal production of MNs [43]. The characterization of Sulf1, required to activate high-threshold response to Hedgehog, not only places the MFP cells at the core of the patterning establishment in zebrafish but also highlights a novel mechanism of the temporal control of the Hedgehog signalling, based on the temporal evolution of ligand source identity.

\section{Role of Shh Provided by Lateral Floor Plate (LFP) Cells}

\subsection{Formation and Identity of LFP Cells}

The existence of two distinct types of FP cells was initially proposed following observation of differences in the spatial expression of FP molecular markers. In the chick and zebrafish neural tube, Foxa2 and other floor plate markers such as Netrin-1 or Fkd4, were shown to display a broader domain of expression than that of Shh $[15,59,94,120-123]$. The inner cells were then named MFP cells, while cells located on either side and displaying a partial floor plate character were named LFP cells. Therefore, LFP cells were so called in the literature before being identified as prospective Shh-producing cells $[15,94,122,123]$. It was only after the observation that these cells activate the expression of Shh in chicken and zebrafish that the LFP was considered to be a secondary source of the morphogen in the developing spinal cord [40,43,59]. Initiation of Shh expression in LFP cells is a late event that occurs long after establishment of the neural tube patterning and onset of neuronal production in chicks and zebrafish [40,43,59] but also in mice (Ohayon, D., Escalas, N., Danesin, C. and Soula C., CBD, University of Toulouse, France. Unpublished work, 2017). At the same time, induction of this secondary source of Shh was recognised to occur within the Nkx2.2-expressing p3 progenitor domain that earlier on generated V3 ventral interneurons $[43,59,121]$. Therefore, ventral cells of the neural tube, initially named LFP cells because they express the floor plate marker Foxa2 but not Shh, are nothing more than neural progenitor cells of the $\mathrm{p} 3$ domain. To avoid any confusion, in the following sections the terminology LFP is used for p3 cells only from the time these cells gain expression of Shh. On the basis of this definition, LFP cells are characterised by the expression of a set of markers also expressed in MFP cells, including Foxa2 and Shh, as previously mentioned, but also Sulf1 [43,124]. As reported for MFP cells [20,29], LFP cells rapidly become refractory to Shh as they differentiate [42,43]. However, in contrast to MFP cells that must downregulate Nkx2.2 to achieve their differentiation program [29], LFP cells maintain Nkx2.2 expression [43,59]. Of note, this is far from being at odds with decay of Shh signalling in LFP cells since maintenance of Nkx2.2 expression is known to no longer depend on Shh at the time of LFP induction $[33,39,43]$. As mentioned above, Foxa2, expressed at a high level in MFP prospective cells, is also activated but at a lower level in ventral neural progenitor cells of the prospective $\mathrm{p} 3$ domain $[28,29]$. This transcription factor, known to be necessary and sufficient to induce Shh expression $[29,67,69]$, remains expressed until the time of LFP induction, suggesting that it might also be involved in Shh upregulation in prospective LFP cells of the p3 domain [43,59]. However, the long period between the onset of Foxa2 expression and Shh upregulation in these cells suggest that additional factors might be required for LFP differentiation. Although the timing of LFP differentiation has been precisely defined in the chick and zebrafish, the mechanisms responsible for induction of this secondary source of Shh are largely unknown. Although grafts of notochord or MFP cells close to the neural tube are able to induce ectopic formation of LFP cells, the long period of time required to obtain a full LFP character ( $3-5$ days) precludes coming to a conclusion as to the direct effect of Shh signalling [59]. Whether differentiation of LFP cells depends on Shh, which is still provided by MFP cells at the time of LFP formation, therefore remains an open question. 


\subsection{Is There a Specific Function for LFP-Derived Shh?}

A set of conclusive arguments favouring a decisive role for LFP-derived Shh in the control of gliogenesis has recently emerged. Such a link was first proposed when it was realised that the formation of this secondary source of Shh is temporally correlated with the induction of oligodendrocyte precursor cells (OPC) from progenitor cells of the pMN domain [43]. Shh signalling being still required at these late stages for induction of OPCs [37-40,43], it was tempting to think that formation of this novel source of Shh might represent a definitive signal for triggering the neuroglial switch. Accordingly, a temporal rise in Shh signalling activity, assessed by upregulation of the Shh responsive genes Ptc1 and Gli1 in progenitor cells of the pMN domain, was further shown to occur at the onset of OPC generation [41-43]. Thus, after a decline of Shh signalling during the neurogenic period [20,27], Shh activity appears to peak again long after the establishment of the neural patterning (from hours in zebrafish to days in amniotes). In agreement, the high-threshold, Shh-responsive gene Nkx2.2 is at that time activated in Olig2-expressing progenitor cells, leading to formation of a new domain ( $\mathrm{p}^{*}$ domain) populated by cells co-expressing Nkx2.2 and Olig2 [39,42-46]. Therefore, LFP differentiation, by bringing a source of Shh into closer proximity to Olig2 progenitor cells, likely contributes to creating the burst of Shh required to change the fate of $\mathrm{pMN}$ progenitor cells, from producing MNs to generating OPCs. However, at the time of patterning rearrangement, $\mathrm{Shh}$ is still expressed in MFP cells $[42,43,59]$. Therefore, to assign this role specifically to LFP-derived Shh, one must be able to prevent expression of Shh in LFP cells without affecting it in MFP cells. Although this has not been directly tested, work performed to unravel the role of Sulf1 in OPC induction further supports the view that Shh provided by MFP cells is dispensable for formation of the $\mathrm{p}^{*}$ domain and thereby specification of OPC [42,43]. Sulf1, whose expression is restricted to MFP cells over the period of neuronal production, is upregulated in LFP cells just after their formation [43]. Experiments performed in chick embryo showed that downregulating Sulf1, specifically in the LFP, is sufficient to impair OPC specification, whereas these cells develop properly when knockdown of Sulf1 is limited to the MFP [42]. Although further work is needed to ascertain that Shh provided by the MFP is not required for triggering the MN to OPC fate switch, these observations indicate that the LFP-derived Shh plays a prime role in controlling the temporal fate change of at least a subset of progenitor cells.

\section{Conclusions}

In the developing neural tube, differential cellular responses to Shh are known to be mediated by the competence of the receiving cells that change with time, by the dose of the morphogen provided to the receiving cells but also by the duration of the signal. These complex processes are paralleled by temporal dynamics of Shh source cells. The notochord is the first localised source of Shh; then the source moves to the MFP and, finally, an additional source, the LFP, is added. Prevalent roles for each source can be proposed at different developmental periods. The notochord should be considered the essential actor of the neuronal cell diversification in the ventral neural tube. The MFP should be seen as the main guarantor of maintenance of the work done by the notochord. Finally, the LFP, by changing the fate of neural progenitor cells, should be recognised as an additional provider of cell diversification in the developing spinal cord. What could be the relative input of moving the Shh sources over time? Moving the morphogen source changes the position of the receiving cells relative to the source and is also expected to increase the morphogen levels in front of it. The amplitude of the Shh gradient is known to change as the ventral neural tube is patterned $[19,20]$ and the successive formations of the MFP and, later on, LFP are likely to contribute to generating cell diversity by changing the spatial profile of the Shh gradient. Lastly, while MFP formation is known to come from the intersection of FGF signalling and the Shh gradient itself [75], the mechanism underlying LFP induction has yet to be determined. Distinct neuronal populations, already differentiated at the time of LFP induction, are known to become providers of FGFs [3]. It is therefore tempting to speculate that prospective LFP cells ( $\mathrm{p} 3$ domain) that share many aspects with prospective MFP cells in terms of molecular identity experience the same intersection of FGF and Shh signalling as the prospective 
MFP cells at earlier developmental stages. Understanding how moving the Shh source integrates into the spatiotemporal hierarchy of inductive events that allow for the generation of neural cell diversity remains a future challenge.

Acknowledgments: We are grateful to Philippe Cochard and Bertrand Bénazéraf for helpful comments on the manuscript. Work performed in the C. Soula lab has been supported by the Centre National de la Recherche Scientifique (CNRS), the Université Paul Sabatier (UPS), the Ministère de l'Education Nationale et de la Recherche, the Agence Nationale de la Recherche (ANR) and the Fondation pour l'Aide à la Recherche sur la Sclérose En Plaques (ARSEP).

Conflicts of Interest: The authors declare no conflict of interest. The founding sponsors had no role in the design of the study; in the collection, analyses, or interpretation of data; in the writing of the manuscript, and in the decision to publish the results.

\section{Abbreviations}

Shh: Sonic Hedgehog, Hh: Hedgehog, NC: notochord; FP: floor plate; MFP: medial floor plate; LFP: lateral floor plate; MN: motor neuron; OPC: oligodendrocyte precursor cell.

\section{References}

1. Jessell, T.M. Neuronal specification in the spinal cord: Inductive signals and transcriptional codes. Nat. Rev. Genet. 2000, 1, 20-29. [CrossRef] [PubMed]

2. Dessaud, E.; McMahon, A.P.; Briscoe, J. Pattern formation in the vertebrate neural tube: A sonic hedgehog morphogen-regulated transcriptional network. Development 2008, 135, 2489-2503. [CrossRef] [PubMed]

3. Guillemot, F; Zimmer, C. From cradle to grave: The multiple roles of fibroblast growth factors in neural development. Neuron 2011, 71, 574-588. [CrossRef] [PubMed]

4. Briscoe, J.; Pierani, A.; Jessell, T.M.; Ericson, J. A homeodomain protein code specifies progenitor cell identity and neuronal fate in the ventral neural tube. Cell 2000, 101, 435-445. [CrossRef]

5. Rowitch, D.H.; Kriegstein, A.R. Developmental genetics of vertebrate glial-cell specification. Nature 2010, 468, 214-222. [CrossRef] [PubMed]

6. Muroyama, Y.; Fujiwara, Y.; Orkin, S.H.; Rowitch, D.H. Specification of astrocytes by bhlh protein scl in a restricted region of the neural tube. Nature 2005, 438, 360-363. [CrossRef] [PubMed]

7. Hochstim, C.; Deneen, B.; Lukaszewicz, A.; Zhou, Q.; Anderson, D.J. Identification of positionally distinct astrocyte subtypes whose identities are specified by a homeodomain code. Cell 2008, 133, 510-522. [CrossRef] [PubMed]

8. Tsai, H.H.; Li, H.; Fuentealba, L.C.; Molofsky, A.V.; Taveira-Marques, R.; Zhuang, H.; Tenney, A.; Murnen, A.T.; Fancy, S.P.; Merkle, F.; et al. Regional astrocyte allocation regulates cns synaptogenesis and repair. Science 2012, 337, 358-362. [CrossRef] [PubMed]

9. Zhou, Q.; Anderson, D.J. The bhlh transcription factors olig2 and olig1 couple neuronal and glial subtype specification. Cell 2002, 109, 61-73. [CrossRef]

10. Lu, Q.R.; Sun, T.; Zhu, Z.; Ma, N.; Garcia, M.; Stiles, C.D.; Rowitch, D.H. Common developmental requirement for olig function indicates a motor neuron/oligodendrocyte connection. Cell 2002, 109, 75-86. [CrossRef]

11. Takebayashi, H.; Nabeshima, Y.; Yoshida, S.; Chisaka, O.; Ikenaka, K. The basic helix-loop-helix factor olig2 is essential for the development of motoneuron and oligodendrocyte lineages. Curr. Biol. 2002, 12, 1157-1163. [CrossRef]

12. Park, H.C.; Mehta, A.; Richardson, J.S.; Appel, B. Olig2 is required for zebrafish primary motor neuron and oligodendrocyte development. Dev. Biol. 2002, 248, 356-368. [CrossRef] [PubMed]

13. Echelard, Y.; Epstein, D.J.; St-Jacques, B.; Shen, L.; Mohler, J.; McMahon, J.A.; McMahon, A.P. Sonic hedgehog, a member of a family of putative signaling molecules, is implicated in the regulation of CNS polarity. Cell 1993, 75, 1417-1430. [CrossRef]

14. Roelink, H.; Augsburger, A.; Heemskerk, J.; Korzh, V.; Norlin, S.; Ruiz i Altaba, A.; Tanabe, Y.; Placzek, M.; Edlund, T.; Jessell, T.M. Floor plate and motor neuron induction by vhh-1, a vertebrate homolog of hedgehog expressed by the notochord. Cell 1994, 76, 761-775. [CrossRef]

15. Martí, E.; Takada, R.; Bumcrot, D.A.; Sasaki, H.; McMahon, A.P. Distribution of sonic hedgehog peptides in the developing chick and mouse embryo. Development 1995, 121, 2537-2547. [PubMed] 
16. Roelink, H.; Porter, J.A.; Chiang, C.; Tanabe, Y.; Chang, D.T.; Beachy, P.A.; Jessell, T.M. Floor plate and motor neuron induction by different concentrations of the amino-terminal cleavage product of sonic hedgehog autoproteolysis. Cell 1995, 81, 445-455. [CrossRef]

17. Placzek, M.; Briscoe, J. The floor plate: Multiple cells, multiple signals. Nat. Rev. Neurosci. 2005, 6, 230-240. [CrossRef] [PubMed]

18. Gritli-Linde, A.; Lewis, P.; McMahon, A.P.; Linde, A. The whereabouts of a morphogen: Direct evidence for short- and graded long-range activity of hedgehog signaling peptides. Dev. Biol. 2001, 236, 364-386. [CrossRef] [PubMed]

19. Chamberlain, C.E.; Jeong, J.; Guo, C.; Allen, B.L.; McMahon, A.P. Notochord-derived shh concentrates in close association with the apically positioned basal body in neural target cells and forms a dynamic gradient during neural patterning. Development 2008, 135, 1097-1106. [CrossRef] [PubMed]

20. Cohen, M.; Kicheva, A.; Ribeiro, A.; Blassberg, R.; Page, K.M.; Barnes, C.P.; Briscoe, J. Ptch1 and gli regulate shh signalling dynamics via multiple mechanisms. Nat. Commun. 2015, 6, 6709. [CrossRef] [PubMed]

21. Briscoe, J.; Thérond, P.P. The mechanisms of hedgehog signalling and its roles in development and disease. Nat. Rev. Mol. Cell Biol. 2013, 14, 418-431. [CrossRef] [PubMed]

22. Briscoe, J.; Ericson, J. Specification of neuronal fates in the ventral neural tube. Curr. Opin. Neurobiol. 2001, 11, 43-49. [CrossRef]

23. Ribes, V.; Briscoe, J. Establishing and interpreting graded sonic hedgehog signaling during vertebrate neural tube patterning: The role of negative feedback. Cold Spring Harb. Perspect. Biol. 2009, 1, a002014. [CrossRef] [PubMed]

24. Dessaud, E.; Yang, L.L.; Hill, K.; Cox, B.; Ulloa, F.; Ribeiro, A.; Mynett, A.; Novitch, B.G.; Briscoe, J. Interpretation of the sonic hedgehog morphogen gradient by a temporal adaptation mechanism. Nature 2007, 450, 717-720. [CrossRef] [PubMed]

25. Dessaud, E.; Ribes, V.; Balaskas, N.; Yang, L.L.; Pierani, A.; Kicheva, A.; Novitch, B.G.; Briscoe, J.; Sasai, N. Dynamic assignment and maintenance of positional identity in the ventral neural tube by the morphogen sonic hedgehog. PLoS Biol. 2010, 8, e1000382. [CrossRef] [PubMed]

26. Jeong, J.; McMahon, A.P. Growth and pattern of the mammalian neural tube are governed by partially overlapping feedback activities of the hedgehog antagonists patched 1 and hhip1. Development 2005, 132, 143-154. [CrossRef] [PubMed]

27. Balaskas, N.; Ribeiro, A.; Panovska, J.; Dessaud, E.; Sasai, N.; Page, K.M.; Briscoe, J.; Ribes, V. Gene regulatory logic for reading the sonic hedgehog signaling gradient in the vertebrate neural tube. Cell 2012, 148, 273-284. [CrossRef] [PubMed]

28. Lek, M.; Dias, J.M.; Marklund, U.; Uhde, C.W.; Kurdija, S.; Lei, Q.; Sussel, L.; Rubenstein, J.L.; Matise, M.P.; Arnold, H.H.; et al. A homeodomain feedback circuit underlies step-function interpretation of a shh morphogen gradient during ventral neural patterning. Development 2010, 137, 4051-4060. [CrossRef] [PubMed]

29. Ribes, V.; Balaskas, N.; Sasai, N.; Cruz, C.; Dessaud, E.; Cayuso, J.; Tozer, S.; Yang, L.L.; Novitch, B.; Marti, E.; et al. Distinct sonic hedgehog signaling dynamics specify floor plate and ventral neuronal progenitors in the vertebrate neural tube. Genes Dev. 2010, 24, 1186-1200. [CrossRef] [PubMed]

30. Wang, H.; Lei, Q.; Oosterveen, T.; Ericson, J.; Matise, M.P. Tcf/lef repressors differentially regulate shh-gli target gene activation thresholds to generate progenitor patterning in the developing CNS. Development 2011, 138, 3711-3721. [CrossRef] [PubMed]

31. Vokes, S.A.; Ji, H.; McCuine, S.; Tenzen, T.; Giles, S.; Zhong, S.; Longabaugh, W.J.; Davidson, E.H.; Wong, W.H.; McMahon, A.P. Genomic characterization of gli-activator targets in sonic hedgehog-mediated neural patterning. Development 2007, 134, 1977-1989. [CrossRef] [PubMed]

32. Peterson, K.A.; Nishi, Y.; Ma, W.; Vedenko, A.; Shokri, L.; Zhang, X.; McFarlane, M.; Baizabal, J.M.; Junker, J.P.; van Oudenaarden, A.; et al. Neural-specific sox2 input and differential gli-binding affinity provide context and positional information in shh-directed neural patterning. Genes Dev. 2012, 26, 2802-2816. [CrossRef] [PubMed]

33. Allen, B.L.; Song, J.Y.; Izzi, L.; Althaus, I.W.; Kang, J.S.; Charron, F.; Krauss, R.S.; McMahon, A.P. Overlapping roles and collective requirement for the coreceptors gas1, cdo, and boc in shh pathway function. Dev. Cell 2011, 20, 775-787. [CrossRef] [PubMed] 
34. Rowitch, D.H. Glial specification in the vertebrate neural tube. Nat. Rev. Neurosci. 2004, 5, 409-419. [CrossRef] [PubMed]

35. Bergles, D.E.; Richardson, W.D. Oligodendrocyte development and plasticity. Cold Spring Harb. Perspect. Biol. 2015, 8, a020453. [CrossRef] [PubMed]

36. Ravanelli, A.M.; Appel, B. Motor neurons and oligodendrocytes arise from distinct cell lineages by progenitor recruitment. Genes Dev. 2015, 29, 2504-2515. [CrossRef] [PubMed]

37. Orentas, D.M.; Hayes, J.E.; Dyer, K.L.; Miller, R.H. Sonic hedgehog signaling is required during the appearance of spinal cord oligodendrocyte precursors. Development 1999, 126, 2419-2429. [PubMed]

38. Soula, C.; Danesin, C.; Kan, P.; Grob, M.; Poncet, C.; Cochard, P. Distinct sites of origin of oligodendrocytes and somatic motoneurons in the chick spinal cord: Oligodendrocytes arise from nkx2.2-expressing progenitors by a shh-dependent mechanism. Development 2001, 128, 1369-1379. [PubMed]

39. Agius, E.; Soukkarieh, C.; Danesin, C.; Kan, P.; Takebayashi, H.; Soula, C.; Cochard, P. Converse control of oligodendrocyte and astrocyte lineage development by sonic hedgehog in the chick spinal cord. Dev. Biol. 2004, 270, 308-321. [CrossRef] [PubMed]

40. Park, H.C.; Shin, J.; Appel, B. Spatial and temporal regulation of ventral spinal cord precursor specification by hedgehog signaling. Development 2004, 131, 5959-5969. [CrossRef] [PubMed]

41. Danesin, C.; Agius, E.; Escalas, N.; Ai, X.; Emerson, C.; Cochard, P.; Soula, C. Ventral neural progenitors switch toward an oligodendroglial fate in response to increased sonic hedgehog (shh) activity: Involvement of sulfatase 1 in modulating shh signaling in the ventral spinal cord. J. Neurosci. 2006, 26, 5037-5048. [CrossRef] [PubMed]

42. Touahri, Y.; Escalas, N.; Benazeraf, B.; Cochard, P.; Danesin, C.; Soula, C. Sulfatase 1 promotes the motor neuron-to-oligodendrocyte fate switch by activating shh signaling in olig2 progenitors of the embryonic ventral spinal cord. J. Neurosci. 2012, 32, 18018-18034. [CrossRef] [PubMed]

43. Al Oustah, A.; Danesin, C.; Khouri-Farah, N.; Farreny, M.A.; Escalas, N.; Cochard, P.; Glise, B.; Soula, C. Dynamics of sonic hedgehog signaling in the ventral spinal cord are controlled by intrinsic changes in source cells requiring sulfatase 1. Development 2014, 141, 1392-1403. [CrossRef] [PubMed]

44. Zhou, Q.; Choi, G.; Anderson, D.J. The bhlh transcription factor olig2 promotes oligodendrocyte differentiation in collaboration with nkx2.2. Neuron 2001, 31, 791-807. [CrossRef]

45. Qi, Y.; Cai, J.; Wu, Y.; Wu, R.; Lee, J.; Fu, H.; Rao, M.; Sussel, L.; Rubenstein, J.; Qiu, M. Control of oligodendrocyte differentiation by the $\mathrm{nkx2.2}$ homeodomain transcription factor. Development 2001, 128, 2723-2733. [PubMed]

46. Fu, H.; Qi, Y.; Tan, M.; Cai, J.; Takebayashi, H.; Nakafuku, M.; Richardson, W.; Qiu, M. Dual origin of spinal oligodendrocyte progenitors and evidence for the cooperative role of olig2 and nkx2.2 in the control of oligodendrocyte differentiation. Development 2002, 129, 681-693. [PubMed]

47. Dodd, J.; Jessell, T.M.; Placzek, M. The when and where of floor plate induction. Science 1998, 282, $1654-1657$. [CrossRef] [PubMed]

48. Placzek, M.; Dodd, J.; Jessell, T.M. Discussion point. The case for floor plate induction by the notochord. Curr. Opin. Neurobiol. 2000, 10, 15-22. [CrossRef]

49. Van Straaten, H.W.; Hekking, J.W.; Wiertz-Hoessels, E.J.; Thors, F.; Drukker, J. Effect of the notochord on the differentiation of a floor plate area in the neural tube of the chick embryo. Anat. Embryol. (Berl) 1988, 177, 317-324. [CrossRef] [PubMed]

50. Smith, J.L.; Schoenwolf, G.C. Notochordal induction of cell wedging in the chick neural plate and its role in neural tube formation. J. Exp. Zool. 1989, 250, 49-62. [CrossRef] [PubMed]

51. Yamada, T.; Placzek, M.; Tanaka, H.; Dodd, J.; Jessell, T.M. Control of cell pattern in the developing nervous system: Polarizing activity of the floor plate and notochord. Cell 1991, 64, 635-647. [CrossRef]

52. Placzek, M.; Tessier-Lavigne, M.; Yamada, T.; Jessell, T.; Dodd, J. Mesodermal control of neural cell identity: Floor plate induction by the notochord. Science 1990, 250, 985-988. [CrossRef] [PubMed]

53. Placzek, M.; Jessell, T.M.; Dodd, J. Induction of floor plate differentiation by contact-dependent, homeogenetic signals. Development 1993, 117, 205-218. [PubMed]

54. Bovolenta, P.; Dodd, J. Perturbation of neuronal differentiation and axon guidance in the spinal cord of mouse embryos lacking a floor plate: Analysis of danforth's short-tail mutation. Development 1991, 113, 625-639. [PubMed] 
55. Clarke, J.D.; Holder, N.; Soffe, S.R.; Storm-Mathisen, J. Neuroanatomical and functional analysis of neural tube formation in notochordless xenopus embryos; laterality of the ventral spinal cord is lost. Development 1991, 112, 499-516. [PubMed]

56. Ruiz i Altaba, A.; Placzek, M.; Baldassare, M.; Dodd, J.; Jessell, T.M. Early stages of notochord and floor plate development in the chick embryo defined by normal and induced expression of hnf-3 beta. Dev. Biol. 1995, 170, 299-313. [CrossRef] [PubMed]

57. Ericson, J.; Morton, S.; Kawakami, A.; Roelink, H.; Jessell, T.M. Two critical periods of sonic hedgehog signaling required for the specification of motor neuron identity. Cell 1996, 87, 661-673. [CrossRef]

58. Strähle, U.; Lam, C.S.; Ertzer, R.; Rastegar, S. Vertebrate floor-plate specification: Variations on common themes. Trends Genet. 2004, 20, 155-162. [CrossRef] [PubMed]

59. Charrier, J.B.; Lapointe, F.; Le Douarin, N.M.; Teillet, M.A. Dual origin of the floor plate in the avian embryo. Development 2002, 129, 4785-4796. [PubMed]

60. Cho, G.; Lim, Y.; Cho, I.T.; Simonet, J.C.; Golden, J.A. Arx together with foxa2, regulates shh floor plate expression. Dev. Biol. 2014, 393, 137-148. [CrossRef] [PubMed]

61. Krauss, S.; Concordet, J.P.; Ingham, P.W. A functionally conserved homolog of the drosophila segment polarity gene hh is expressed in tissues with polarizing activity in zebrafish embryos. Cell 1993, 75, 1431-1444. [CrossRef]

62. England, S.; Batista, M.F.; Mich, J.K.; Chen, J.K.; Lewis, K.E. Roles of hedgehog pathway components and retinoic acid signalling in specifying zebrafish ventral spinal cord neurons. Development 2011, 138, 5121-5134. [CrossRef] [PubMed]

63. Chiang, C.; Litingtung, Y.; Lee, E.; Young, K.E.; Corden, J.L.; Westphal, H.; Beachy, P.A. Cyclopia and defective axial patterning in mice lacking sonic hedgehog gene function. Nature 1996, 383, 407-413. [CrossRef] [PubMed]

64. Pierani, A.; Brenner-Morton, S.; Chiang, C.; Jessell, T.M. A sonic hedgehog-independent, retinoid-activated pathway of neurogenesis in the ventral spinal cord. Cell 1999, 97, 903-915. [CrossRef]

65. Wijgerde, M.; McMahon, J.A.; Rule, M.; McMahon, A.P. A direct requirement for hedgehog signaling for normal specification of all ventral progenitor domains in the presumptive mammalian spinal cord. Genes Dev. 2002, 16, 2849-2864. [CrossRef] [PubMed]

66. Ericson, J.; Briscoe, J.; Rashbass, P.; van Heyningen, V.; Jessell, T.M. Graded sonic hedgehog signaling and the specification of cell fate in the ventral neural tube. Cold Spring Harb. Symp. Quant. Biol. 1997, 62, 451-466. [PubMed]

67. Sasaki, H.; Hogan, B.L. Hnf-3 beta as a regulator of floor plate development. Cell 1994, 76, 103-115. [CrossRef]

68. Sasaki, H.; Hui, C.; Nakafuku, M.; Kondoh, H. A binding site for gli proteins is essential for hnf-3beta floor plate enhancer activity in transgenics and can respond to shh in vitro. Development 1997, 124, 1313-1322. [PubMed]

69. Jeong, Y.; Epstein, D.J. Distinct regulators of shh transcription in the floor plate and notochord indicate separate origins for these tissues in the mouse node. Development 2003, 130, 3891-3902. [CrossRef] [PubMed]

70. Lei, Q.; Jeong, Y.; Misra, K.; Li, S.; Zelman, A.K.; Epstein, D.J.; Matise, M.P. Wnt signaling inhibitors regulate the transcriptional response to morphogenetic shh-gli signaling in the neural tube. Dev. Cell 2006, 11, 325-337. [CrossRef] [PubMed]

71. Oosterveen, T.; Kurdija, S.; Alekseenko, Z.; Uhde, C.W.; Bergsland, M.; Sandberg, M.; Andersson, E.; Dias, J.M.; Muhr, J.; Ericson, J. Mechanistic differences in the transcriptional interpretation of local and long-range shh morphogen signaling. Dev. Cell 2012, 23, 1006-1019. [CrossRef] [PubMed]

72. Tenzen, T.; Allen, B.L.; Cole, F.; Kang, J.S.; Krauss, R.S.; McMahon, A.P. The cell surface membrane proteins cdo and boc are components and targets of the hedgehog signaling pathway and feedback network in mice. Dev. Cell 2006, 10, 647-656. [CrossRef] [PubMed]

73. Allen, B.L.; Tenzen, T.; McMahon, A.P. The hedgehog-binding proteins gas1 and cdo cooperate to positively regulate shh signaling during mouse development. Genes Dev. 2007, 21, 1244-1257. [CrossRef] [PubMed]

74. Martinelli, D.C.; Fan, C.M. Gas1 extends the range of hedgehog action by facilitating its signaling. Genes Dev. 2007, 21, 1231-1243. [CrossRef] [PubMed]

75. Sasai, N.; Kutejova, E.; Briscoe, J. Integration of signals along orthogonal axes of the vertebrate neural tube controls progenitor competence and increases cell diversity. PLoS Biol. 2014, 12, e1001907. [CrossRef] [PubMed] 
76. Matise, M.P.; Epstein, D.J.; Park, H.L.; Platt, K.A.; Joyner, A.L. Gli2 is required for induction of floor plate and adjacent cells, but not most ventral neurons in the mouse central nervous system. Development 1998, 125, 2759-2770. [PubMed]

77. Bai, C.B.; Joyner, A.L. Gli1 can rescue the in vivo function of gli2. Development 2001, 128, 5161-5172. [PubMed]

78. Bai, C.B.; Auerbach, W.; Lee, J.S.; Stephen, D.; Joyner, A.L. Gli2, but not gli1, is required for initial shh signaling and ectopic activation of the shh pathway. Development 2002, 129, 4753-4761. [PubMed]

79. Mansour, A.A.; Nissim-Eliraz, E.; Zisman, S.; Golan-Lev, T.; Schatz, O.; Klar, A.; Ben-Arie, N. Foxa2 regulates the expression of nato3 in the floor plate by a novel evolutionarily conserved promoter. Mol. Cell. Neurosci. 2011, 46, 187-199. [CrossRef] [PubMed]

80. Mansour, A.A.; Khazanov-Zisman, S.; Netser, Y.; Klar, A.; Ben-Arie, N. Nato3 plays an integral role in dorsoventral patterning of the spinal cord by segregating floor plate/p3 fates via nkx2.2 suppression and foxa2 maintenance. Development 2014, 141, 574-584. [CrossRef] [PubMed]

81. Yu, K.; McGlynn, S.; Matise, M.P. Floor plate-derived sonic hedgehog regulates glial and ependymal cell fates in the developing spinal cord. Development 2013, 140, 1594-1604. [CrossRef] [PubMed]

82. Ding, Q.; Motoyama, J.; Gasca, S.; Mo, R.; Sasaki, H.; Rossant, J.; Hui, C.C. Diminished sonic hedgehog signaling and lack of floor plate differentiation in gli2 mutant mice. Development 1998, 125, 2533-2543. [PubMed]

83. Kicheva, A.; Bollenbach, T.; Ribeiro, A.; Valle, H.P.; Lovell-Badge, R.; Episkopou, V.; Briscoe, J. Coordination of progenitor specification and growth in mouse and chick spinal cord. Science 2014, 345, 1254927. [CrossRef] [PubMed]

84. Charrier, J.B.; Lapointe, F.; Le Douarin, N.M.; Teillet, M.A. Anti-apoptotic role of sonic hedgehog protein at the early stages of nervous system organogenesis. Development 2001, 128, 4011-4020. [PubMed]

85. Van Straaten, H.W.; Hekking, J.W. Development of floor plate, neurons and axonal outgrowth pattern in the early spinal cord of the notochord-deficient chick embryo. Anat. Embryol. (Berl) 1991, 184, 55-63. [CrossRef] [PubMed]

86. Van Straaten, H.W.; Hekking, J.W.; Beursgens, J.P.; Terwindt-Rouwenhorst, E.; Drukker, J. Effect of the notochord on proliferation and differentiation in the neural tube of the chick embryo. Development 1989, 107, 793-803. [CrossRef]

87. Rowitch, D.H.; S-Jacques, B.; Lee, S.M.; Flax, J.D.; Snyder, E.Y.; McMahon, A.P. Sonic hedgehog regulates proliferation and inhibits differentiation of cns precursor cells. J. Neurosci. 1999, 19, 8954-8965. [PubMed]

88. Goodrich, L.V.; Milenković, L.; Higgins, K.M.; Scott, M.P. Altered neural cell fates and medulloblastoma in mouse patched mutants. Science 1997, 277, 1109-1113. [CrossRef] [PubMed]

89. Hynes, M.; Ye, W.; Wang, K.; Stone, D.; Murone, M.; Sauvage, F.; Rosenthal, A. The seven-transmembrane receptor smoothened cell-autonomously induces multiple ventral cell types. Nat. Neurosci. 2000, 3, 41-46. [CrossRef] [PubMed]

90. Halpern, M.E.; Ho, R.K.; Walker, C.; Kimmel, C.B. Induction of muscle pioneers and floor plate is distinguished by the zebrafish no tail mutation. Cell 1993, 75, 99-111. [CrossRef]

91. Schulte-Merker, S.; van Eeden, F.J.; Halpern, M.E.; Kimmel, C.B.; Nüsslein-Volhard, C. No tail (ntl) is the zebrafish homologue of the mouse $t$ (brachyury) gene. Development 1994, 120, 1009-1015. [PubMed]

92. Brand, M.; Heisenberg, C.P.; Warga, R.M.; Pelegri, F.; Karlstrom, R.O.; Beuchle, D.; Picker, A.; Jiang, Y.J.; Furutani-Seiki, M.; van Eeden, F.J.; et al. Mutations affecting development of the midline and general body shape during zebrafish embryogenesis. Development 1996, 123, 129-142. [PubMed]

93. Schauerte, H.E.; van Eeden, F.J.; Fricke, C.; Odenthal, J.; Strahle, U.; Haffter, P. Sonic hedgehog is not required for the induction of medial floor plate cells in the zebrafish. Development 1998, 125, 2983-2993. [PubMed]

94. Odenthal, J.; van Eeden, F.J.; Haffter, P.; Ingham, P.W.; Nüsslein-Volhard, C. Two distinct cell populations in the floor plate of the zebrafish are induced by different pathways. Dev. Biol. 2000, 219, 350-363. [CrossRef] [PubMed]

95. Currie, P.D.; Ingham, P.W. Induction of a specific muscle cell type by a hedgehog-like protein in zebrafish. Nature 1996, 382, 452-455. [CrossRef] [PubMed]

96. Zardoya, R.; Abouheif, E.; Meyer, A. Evolution and orthology of hedgehog genes. Trends Genet. 1996, 12, 496-497. [CrossRef] 
97. Ekker, S.C.; Ungar, A.R.; Greenstein, P.; von Kessler, D.P.; Porter, J.A.; Moon, R.T.; Beachy, P.A. Patterning activities of vertebrate hedgehog proteins in the developing eye and brain. Curr. Biol. 1995, 5, 944-955. [CrossRef]

98. Etheridge, L.A.; Wu, T.; Liang, J.O.; Ekker, S.C.; Halpern, M.E. Floor plate develops upon depletion of tiggy-winkle and sonic hedgehog. Genesis 2001, 30, 164-169. [CrossRef] [PubMed]

99. Lewis, K.E.; Eisen, J.S. Hedgehog signaling is required for primary motoneuron induction in zebrafish. Development 2001, 128, 3485-3495. [PubMed]

100. Chen, W.; Burgess, S.; Hopkins, N. Analysis of the zebrafish smoothened mutant reveals conserved and divergent functions of hedgehog activity. Development 2001, 128, 2385-2396. [PubMed]

101. Karlstrom, R.O.; Talbot, W.S.; Schier, A.F. Comparative synteny cloning of zebrafish you-too: Mutations in the hedgehog target gli2 affect ventral forebrain patterning. Genes Dev. 1999, 13, 388-393. [CrossRef] [PubMed]

102. Varga, Z.M.; Amores, A.; Lewis, K.E.; Yan, Y.L.; Postlethwait, J.H.; Eisen, J.S.; Westerfield, M. Zebrafish smoothened functions in ventral neural tube specification and axon tract formation. Development 2001, 128, 3497-3509. [PubMed]

103. Hatta, K.; Kimmel, C.B.; Ho, R.K.; Walker, C. The cyclops mutation blocks specification of the floor plate of the zebrafish central nervous system. Nature 1991, 350, 339-341. [CrossRef] [PubMed]

104. Rebagliati, M.R.; Toyama, R.; Haffter, P.; Dawid, I.B. Cyclops encodes a nodal-related factor involved in midline signaling. Proc. Natl. Acad. Sci. USA 1998, 95, 9932-9937. [CrossRef] [PubMed]

105. Feldman, B.; Gates, M.A.; Egan, E.S.; Dougan, S.T.; Rennebeck, G.; Sirotkin, H.I.; Schier, A.F.; Talbot, W.S. Zebrafish organizer development and germ-layer formation require nodal-related signals. Nature 1998, 395, 181-185. [PubMed]

106. Schier, A.F.; Neuhauss, S.C.; Helde, K.A.; Talbot, W.S.; Driever, W. The one-eyed pinhead gene functions in mesoderm and endoderm formation in zebrafish and interacts with no tail. Development 1997, 124, 327-342. [PubMed]

107. Strähle, U.; Jesuthasan, S.; Blader, P.; Garcia-Villalba, P.; Hatta, K.; Ingham, P.W. One-eyed pinhead is required for development of the ventral midline of the zebrafish (danio rerio) neural tube. Genes Funct. 1997, 1, 131-148. [CrossRef] [PubMed]

108. Zhang, J.; Talbot, W.S.; Schier, A.F. Positional cloning identifies zebrafish one-eyed pinhead as a permissive egf-related ligand required during gastrulation. Cell 1998, 92, 241-251. [CrossRef]

109. Strähle, U.; Blader, P.; Henrique, D.; Ingham, P.W. Axial, a zebrafish gene expressed along the developing body axis, shows altered expression in cyclops mutant embryos. Genes Dev. 1993, 7, 1436-1446. [CrossRef] [PubMed]

110. Schafer, M.; Kinzel, D.; Neuner, C.; Schartl, M.; Volff, J.N.; Winkler, C. Hedgehog and retinoid signalling confines nkx2.2b expression to the lateral floor plate of the zebrafish trunk. Mech. Dev. 2005, 122, 43-56. [CrossRef] [PubMed]

111. Albert, S.; Muller, F.; Fischer, N.; Biellmann, D.; Neumann, C.; Blader, P.; Strahle, U. Cyclops-independent floor plate differentiation in zebrafish embryos. Dev. Dyn. 2003, 226, 59-66. [CrossRef] [PubMed]

112. Cayuso, J.; Ulloa, F.; Cox, B.; Briscoe, J.; Martí, E. The sonic hedgehog pathway independently controls the patterning, proliferation and survival of neuroepithelial cells by regulating gli activity. Development 2006, 133, 517-528. [CrossRef] [PubMed]

113. Guner, B.; Karlstrom, R.O. Cloning of zebrafish nkx6.2 and a comprehensive analysis of the conserved transcriptional response to hedgehog/gli signaling in the zebrafish neural tube. Gene Expr. Patterns 2007, 7, 596-605. [CrossRef] [PubMed]

114. Cheesman, S.E.; Layden, M.J.; Von Ohlen, T.; Doe, C.Q.; Eisen, J.S. Zebrafish and fly nkx6 proteins have similar cns expression patterns and regulate motoneuron formation. Development 2004, 131, 5221-5232. [CrossRef] [PubMed]

115. Gribble, S.L.; Nikolaus, O.B.; Dorsky, R.I. Regulation and function of dbx genes in the zebrafish spinal cord. Dev. Dyn. 2007, 236, 3472-3483. [CrossRef] [PubMed]

116. Lewis, K.E.; Bates, J.; Eisen, J.S. Regulation of iro3 expression in the zebrafish spinal cord. Dev. Dyn. 2005, 232, 140-148. [CrossRef] [PubMed]

117. Lamanna, W.C.; Kalus, I.; Padva, M.; Baldwin, R.J.; Merry, C.L.; Dierks, T. The heparanome-the enigma of encoding and decoding heparan sulfate sulfation. J. Biotechnol. 2007, 129, 290-307. [CrossRef] [PubMed] 
118. Wojcinski, A.; Nakato, H.; Soula, C.; Glise, B. Dsulfatase-1 fine-tunes hedgehog patterning activity through a novel regulatory feedback loop. Dev. Biol. 2011, 358, 168-180. [CrossRef] [PubMed]

119. Gorsi, B.; Whelan, S.; Stringer, S.E. Dynamic expression patterns of 6-o endosulfatases during zebrafish development suggest a subfunctionalisation event for sulf2. Dev. Dyn. 2010, 239, 3312-3323. [CrossRef] [PubMed]

120. Barth, K.A.; Wilson, S.W. Expression of zebrafish nk2.2 is influenced by sonic hedgehog/vertebrate hedgehog-1 and demarcates a zone of neuronal differentiation in the embryonic forebrain. Development 1995, 121, 1755-1768. [PubMed]

121. Schäfer, M.; Kinzel, D.; Winkler, C. Discontinuous organization and specification of the lateral floor plate in zebrafish. Dev. Biol. 2007, 301, 117-129. [CrossRef] [PubMed]

122. Odenthal, J.; Nüsslein-Volhard, C. Fork head domain genes in zebrafish. Dev. Genes Evol. 1998, 208, $245-258$. [CrossRef] [PubMed]

123. Strähle, U.; Blader, P.; Ingham, P.W. Expression of axial and sonic hedgehog in wildtype and midline defective zebrafish embryos. Int. J. Dev. Biol. 1996, 40, 929-940. [PubMed]

124. Braquart-Varnier, C.; Danesin, C.; Clouscard-Martinato, C.; Agius, E.; Escalas, N.; Benazeraf, B.; Ai, X.; Emerson, C.; Cochard, P.; Soula, C. A subtractive approach to characterize genes with regionalized expression in the gliogenic ventral neuroepithelium: Identification of chick sulfatase 1 as a new oligodendrocyte lineage gene. Mol. Cell. Neurosci. 2004, 25, 612-628. [CrossRef] [PubMed]

(c) 2017 by the authors. Licensee MDPI, Basel, Switzerland. This article is an open access article distributed under the terms and conditions of the Creative Commons Attribution (CC BY) license (http:/ / creativecommons.org/licenses/by/4.0/). 